\title{
Leaks after Left Atrial Appendage Closure: Ignored or Neglected?
}

\author{
Sun-Joo Jang ${ }^{\text {a }}$ S. Chiu Wong ${ }^{b}$ Bobak Mosadegh $^{a}$ \\ aDalio Institute of Cardiovascular Imaging, New York Presbyterian Hospital and Weill Cornell Medicine, New York,

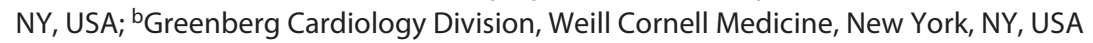

\section{Keywords}

Peri-device leak · Leaks · Left atrial appendage closure ·

Thromboembolism · Atrial fibrillation · Occluders

\begin{abstract}
Left atrial appendage (LAA) closure has recently been approved as an alternative management for stroke prevention in patients with chronic atrial fibrillation who have difficulties with long-term oral anticoagulation. The various shapes and sizes of LAA and orientation of the atrial ostium may contribute to the incomplete LAA closure from circular design devices and orientation of the non-steerable delivery catheter. Incomplete closure of LAA leads to a high-velocity blood flow through the peri-device gap, resulting in peridevice leak (PDL). Residual leaks are frequently diagnosed after LAA closure procedures, regardless of closure methods. There is a controversy in the clinical significance of the leaks, particularly about its association with thromboembolic events. PDL $<5 \mathrm{~mm}$ was not associated with any increase of risk for thromboembolism. Current literatures with small study population have not been sufficient to clarify the role of the leaks after LAA closure. Nevertheless, management of severe leaks has been a challenging concern for cardiolo-
\end{abstract}

\section{karger@karger.com www.karger.com/crd \\ Karger $\stackrel{\text { ' }}{5}$}

GOPEN ACCESS

\section{(C) 2021 The Author(s)}

Published by S. Karger AG, Basel

This is an Open Access article licensed under the Creative Commons Attribution-NonCommercial-4.0 International License (CC BY-NC) (http://www.karger.com/Services/OpenAccessLicense), applicable to the online version of the article only. Usage and distribution for commercial purposes requires written permission. gists. Leaks after epicardial LAA closures are at the neck of the incompletely closed LAA and have shown to increase the risk of thromboembolism. Percutaneous closure of the leaks after LAA closure has been attempted with good safety and success, but long-term safety and efficacy remains unclear. Further large long-term studies which aim to assess the role of leaks or PDLs in predicting thromboembolic events and management strategies are warranted.

(C) 2021 The Author(s)

Published by S. Karger AG, Basel

\section{Introduction}

Atrial fibrillation (AF) is a clinically important cardiac arrhythmia which can cause detrimental complications such as stroke, transient ischemic attack (TIA), myocardial infarction, or other systemic embolism (SE) among high-risk patients. Increasing clinical knowledge and experience in recent years has changed the stroke prevention among patients with AF. Together with current oral anticoagulation strategies, development of device procedures for the closure of the left atrial appendage (LAA) has been changing the clinical practice. However, the residual leak after the closure has been a clinically un- 
neglectable concern. This article aimed to review the thromboembolic risk of the residual leak after LAA closure and to summarize recent data regarding the outcomes of percutaneous intervention for the closure of the leaks.

\section{Methods}

We performed a literature search from MEDLINE/PUBMED from 2008 to 2020 for the most relevant and updated studies including prospective, observational, and retrospective studies, as well as randomized trials that included endocardial or epicardial LAA closure procedures, data for leaks after closure, or data on the incidence of thromboembolism.

\section{LAA and Stroke Prevention in $A F$}

LAA is a remnant of the embryonic left atrium [1]. However, the LAA is not just a passive embryonic remnant, it has been considered as the most lethal human attachment since the majority (i.e., 90\%) of strokes in patients with non-valvular $\mathrm{AF}$ originate from the thrombus formation in the LAA [2]. The prevention of thromboembolic events in this setting are mostly dependent on oral vitamin K antagonists (e.g., warfarin) [3]. Non-vitamin K oral anticoagulants (NOACs), including dabigatran, ribaroxaban, apixaban, and edoxaban, are now preferred pharmacological agents to warfarin for AF patients with a moderate or high risk for ischemic stroke unless they have moderate-to-severe mitral stenosis or mechanical heart valves [4]. However, the risk of bleeding from oral anticoagulation leads to the development of an LAA closure device, as an alternative tool for the prevention of thromboembolism in AF [5]. Percutaneous LAA occlusion may be considered for AF patients at an increased risk of stroke who have contraindications to long-term anticoagulation [4]. A recent randomized clinical trial (PRAGUE-17) comparing percutaneous LAA closure with direct oral anticoagulants showed no differences of stroke/TIA prevention, bleeding, or cardiovascular death between the 2 groups [6].

Multiple percutaneous devices for LAA closure are being developed. Initial experience of the WATCHMAN ${ }^{\mathrm{TM}}$ device from the PROTECT-AF (Watchman Left Atrial Appendage System for Embolic Protection in Patients with Atrial Fibrillation) trial and the PREVAIL (Prospective Randomized Evaluation of the Watchman Left Atrial Appendage Closure Device in Patients With Atrial Fibrillation vs. Long-Term Warfarin Therapy) trial provided the evidence of noninferiority of the device to an oral anticoagulant for stroke prevention and peri-procedural safety [7-10]. The registries of CAP (Continued Access to PROTECT-AF) and CAP2 (Continued Access to PREVAIL) and ASAP study (ASA, Plavix Feasibility Study With Watchman Left Atrial Appendage Closure Technology) also confirmed the efficacy and safety of the WATCHMAN ${ }^{\mathrm{TM}}$ device $[11,12,54]$. The WATCHMAN ${ }^{\mathrm{TM}}$ device was approved by the US Food and Drug Administration (FDA) in March 2015 as a stroke prevention alternative to oral anticoagulants in patients with non-valvular AF who have contraindication for long-term anticoagulation due to high bleeding risk [6]. Post-FDA approval studies for LAA closure have shown promising results with high success and low complication rates [13]. The next-generation WATCHMAN FLX [52] received the CE mark in Europe in March
2019 and received FDA approval in July 2020. Another type of a percutaneous closure device is the AMPLATZER ${ }^{\mathrm{TM}}$ Cardiac Plug or AMPLATZER ${ }^{\mathrm{TM}}$ Amulet $^{\mathrm{TM}}$. AMPLATZER ${ }^{\mathrm{TM}}$ Cardiac Plug received the CE mark in 2008. AMPLATZER ${ }^{\mathrm{TM}}$ Amulet $^{\mathrm{TM}}$ is a second-generation device that received the CE mark in 2013 and is now widely available in Europe and other countries that accept the CE mark. Real-world global registry data showed that the AMPLATZER $^{\text {TM }}$ Amulet ${ }^{\mathrm{TM}}$ device reduced the risk of stroke, TIA, and SE $[14,15]$. Percutaneous epicardial LAA ligation technology using the LARIAT ${ }^{\circledR}$ device (Fig. 1c) has received $510 \mathrm{~K}$ FDA clearance for "tissue ligation" in 2006 and has been applied in closure of LAA with a high success rate (95.5\%) [16, 17]. Surgical ligation/ excision/clipping are also very common procedures that can be combined during the open heart surgery [18-20].

\section{Peri-Device Leak after Percutaneous Device Closure}

The shape and size of the LAA is variable and the orifice is typically elliptical (68.9\%) while percutaneous LAA closure devices are circular [21]. This mismatch in geometry provides the potential for incomplete LAA occlusion and residual peri-device leak (PDL) (Fig. 1a) [22]. In addition, the orientation of the left appendage ostium and the proximal surface of the device may also be malaligned during deployment with resultant PDL. The definition of PDL is arbitrary depending on the devices and imaging modalities. This lack of standardized criteria for leaks may lead to the controversies regarding its relation to thromboembolic events. A PDL is generally defined as the presence of flow past around the edge of an implanted device into the fundus of the LAA, as determined by color Doppler in transesophageal echocardiography (TEE) or the presence of contrast within the LAA on cardiac computed tomography angiography (CCTA) [23, 24]. The definition of significant leak ranges from a 1 to $5 \mathrm{~mm}$ width of residual flow (leak) on color Doppler using TEE. Post WATCHMAN ${ }^{\mathrm{TM}}$ implant, a $>5-\mathrm{mm}$ PDL at 45-day TEE is considered significant and warrants continuation of oral anticoagulation. For the AMPLATZER ${ }^{\mathrm{TM}}$ Cardiac Plug or AMPLATZER ${ }^{\mathrm{TM}}$ Amulet $^{\mathrm{TM}}$ devices, PDL is consider as the presence of a color jet around the device lobe in multiplane images of TEE [23]. The incidence of PDL has been reported in a range of $5 \sim 32 \%$ at a 1 -year follow-up, depending on its definition and different devices [22-27]. The predictor of PDL after LAA closure is not clearly identified, although there is a report showing that the device compression rate of $<10 \%$ is associated with PDL [24].

The clinical correlation of PDL or residual flow is not well established. Studies reporting PDL or residual flow are outlined in Table 1. In the PROTECT-AF trial with the WATCHMAN ${ }^{\mathrm{TM}}$ device, PDL was present in $40.9,33.8$, and $32.1 \%$ of the patients at 45 days, 6 months, and 12 months after WATCHMAN ${ }^{\mathrm{TM}}$ device implantation, respectively [25]. In this study, residual PDL was not associated with an increased risk of thromboembolism regardless of the size of the leak $(<1,1-3$, and $>3 \mathrm{~mm})$. However, the investigators emphasized that the confidence of the results was limited due to small sample size or low event rates in the study. Furthermore, the clinical implication of larger PDLs ( $>5 \mathrm{~mm}$ width) was not evaluated in this study.

The PDL from ACP was assessed in a prospective multicenter study [53]. At 12 months after ACP implantation, PDL was noted in $11.6 \%$ to $12.5 \%$ of patients on follow-up TEE, which was lower than PDL incidence of the WATCHMAN ${ }^{\mathrm{TM}}$ device (32.1\%) [23, 53]. The "lobe-and-disc" design of the ACP device may cover the 

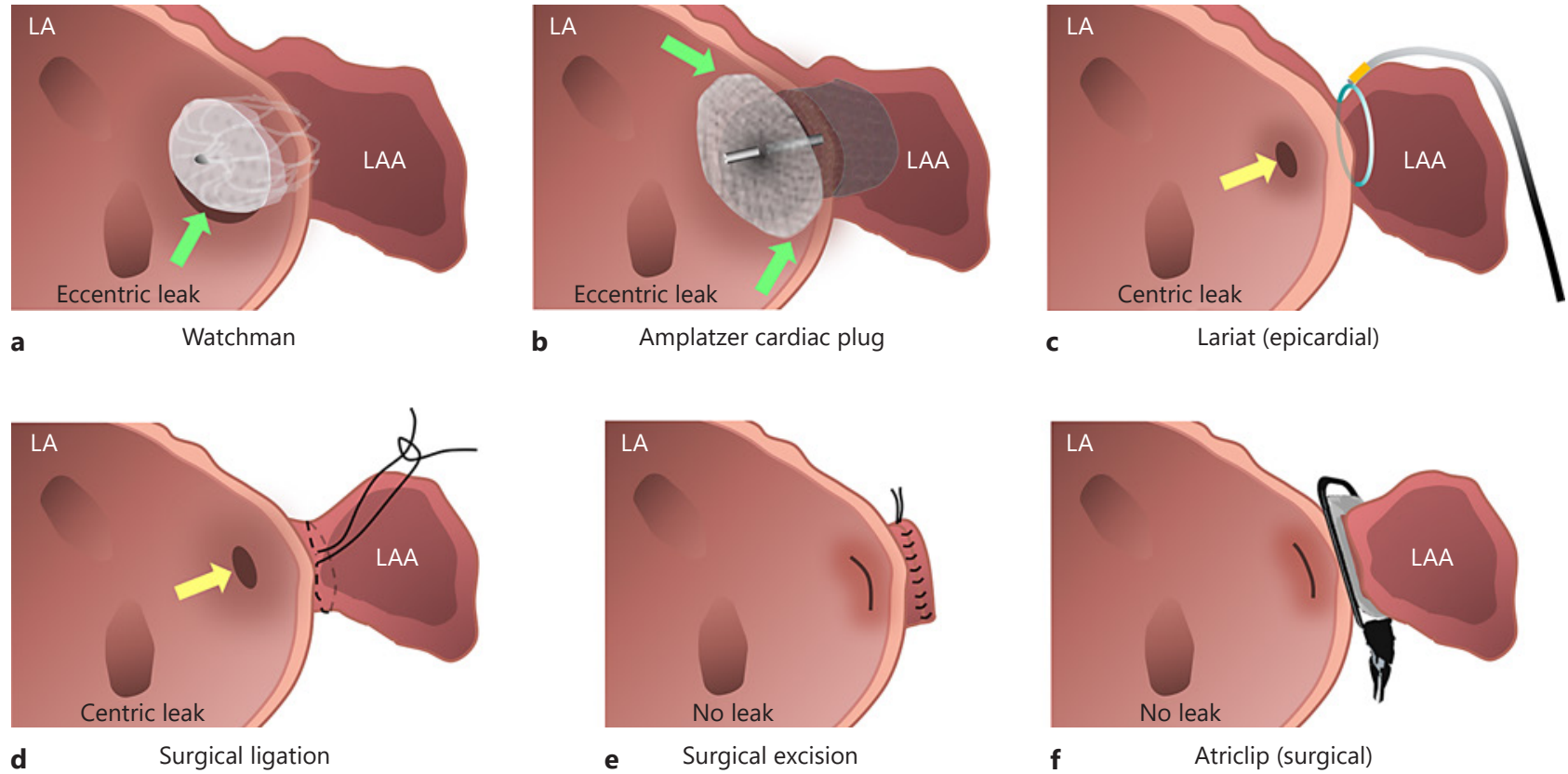

Fig. 1. Schematic illustration of leaks after LAA closure. a Eccentric leak (green arrow) after WATCHMAN ${ }^{\mathrm{TM}}$ device implantation. $\mathbf{b}$ Eccentric leak (green arrow) around the lobe of the AMPLATZER ${ }^{\mathrm{TM}}$ Cardiac Plug device.

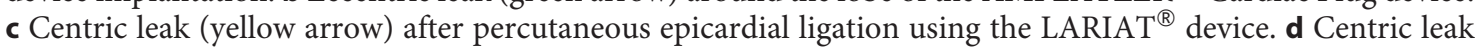
(yellow arrow) through the middle of the appendage ostium after surgical ligation. e No leak after surgical excision of LAA. $f$ No leak after epicardial clipping with ATRICLIP ${ }^{\mathrm{TM}}$. LA, left atrium; LAA, left atrial appendage.

orifice of the LAA and lower the incidence of PDL compared to the "single-lobe" design of the WATCHMAN" device (Fig. 1b). Severe PDL ( $>5 \mathrm{~mm}$ or multiple jets) was in $0.6 \%$ of the population (2/339) and 5\% of all reported PDLs (2/39). However, no independent predictors of PDL or clinical outcomes were identified in this study due to the low study power. Similar findings were also observed in the subgroup of the WATCHMAN ${ }^{\mathrm{TM}}$ device in a study by Pillarisetti et al. [28]. In an imaging study by Nguyen et al. [24], CCTA detected $56.7 \%$ (17/30) of PDL from the mixed device population (WATCHMAN ${ }^{\mathrm{TM}}$, ACP and AMPLATZER ${ }^{\mathrm{TM}}$ Amulet $^{\circledR}$ ). In the study, the incidence of major adverse cardiac event was quantitatively higher in patients with PDL, but the difference was not statistically significant between patients with PDL versus without PDL (12 vs. $4.3 \%, p=0.3$ ) due to small study size.

Although it is not considered a PDL, persistent large accessory lobes adjacent to an LAA that remain unclosed by the occluding device can cause thromboembolism. This event is more common for devices that use the "plug principle," such as Watchman occluders. Devices that use the "pacifier principle," meaning they include a proximal disc, can cover this accessory lobe and, therefore, have a decreased incidence of thromboembolism [29].

\section{Leaks after Epicardial or Surgical LAA Closures}

Epicardial closure using the LARIAT $^{\circledR}$ device was also resulting in the incomplete closure and residual leaks. Fink et al. [30] reported that major leaks $>5 \mathrm{~mm}$ were documented in $11 \%$ of patients with the LARIAT ${ }^{\circledR}$ device but were not associated with thrombo- embolism (only 1 event in the overall cohort). Pillarisetti et al. [28] reported that the leak was found in $14 \%(33 / 259)$ of patients with the LARIAT ${ }^{\circledR}$ device, but thromboembolism cases $(n=3)$ were not associated with the leaks. Among those 3 thromboembolic cases, 2 patients had a delayed stroke without leaks, and 1 patient had a TIA with no thrombus near LAA or any leak. The study explained that the leaks after incomplete LAA exclusion may create a high blood flow through the neck, discouraging the blood stasis and thrombus formation [31] (Fig. 1c). However, there are no large studies for LARIAT $^{\circledR}$ that can provide a more reliable opinion on the association between the leak and thromboembolism.

Surgical approaches, especially suture ligation closures are also reporting high incidence of residual flow (leak) due to the incomplete closure (Fig. 1d). Surgical excision (Fig. 1e) or an epicardial LAA clipping device (ATRICLIPTM) (Fig. 1f) results in no residual leak because LAA is amputated out of the heart [32]. Meanwhile, surgical ligation or stapler exclusion reported incomplete LAA closures in more than one third of the patients $[33,34]$. It is noteworthy that residual leak from incomplete LAA closure from surgery has been reported to be associated with thromboembolic events [34, 35]. The incomplete surgical closure of LAA produces a big empty space in the LAA, which induces turbulent flow, vortex, and stagnation inside that chamber and may lead to the increased risk of thrombosis.

\section{Thrombosis Related to LAA Closure}

Device-related thrombosis (DRT) has been reported in 3-18\% of patients with AF after LAA closure $[7,11,36]$. Pooled analysis 
Table 1. Studies reporting the leak after LAA closure

\begin{tabular}{|c|c|c|c|c|c|c|}
\hline Authors & $\begin{array}{l}\text { Study } \\
\text { population }\end{array}$ & Type of study & Type of LAA closure & Severity of leak ${ }^{*}$ & $\begin{array}{l}\text { Incidence of PDL or } \\
\text { leak, } \%^{\dagger}\end{array}$ & $\begin{array}{l}\text { Association with } \\
\text { thromboembolism }\end{array}$ \\
\hline Osmancik et al. [6] & 201 vs. 201 & $\begin{array}{l}\text { Prospective } \\
\text { randomized trial } \\
\text { (PRAGUE-17) }\end{array}$ & $\begin{array}{l}\text { WATCHMAN }^{\mathrm{TM}} \text {, } \\
\text { WATCHMAN }^{\mathrm{TM}} \\
\text { FLX, } \\
\text { AMPLATZER }^{\mathrm{TM}} \\
\text { Amulet }^{\mathrm{TM}}\end{array}$ & $\leq 5 \mathrm{~mm},>5 \mathrm{~mm}$ & $\begin{array}{l}>5 \text {-mm leak was seen } \\
\text { in } 4(2.2 \%) \text { patients, } \\
1 \text { - to } 5 \text {-mm leaks in } \\
20(11.2 \%) \text {, and no } \\
\text { leak in } 154(86.5 \%)\end{array}$ & Not available \\
\hline Doshi et al. [52] & 400 & $\begin{array}{l}\text { Prospective } \\
\text { observational registry } \\
\text { (PINNACLE FLX) }\end{array}$ & $\begin{array}{l}\text { WATCHMAN }{ }^{\mathrm{TM}} \\
\text { FLX }\end{array}$ & $\begin{array}{l}\geq 5 \mathrm{~mm} \text { as } \\
\text { significant PDL }\end{array}$ & $\begin{array}{l}0 \% \text { for } \geq 5 \mathrm{~mm} \\
10.5 \% \text { with } \\
\text { identifiable leaks }\end{array}$ & $\begin{array}{l}\text { Only } 2 \text { strokes total, } 7 \\
\text { DRTs }\end{array}$ \\
\hline $\begin{array}{l}\text { Landmesser } \\
\text { et al. [14] } \\
\text { Hildick-Smith } \\
\text { et al. [15] }\end{array}$ & 1,088 & $\begin{array}{l}\text { Prospective } \\
\text { observational registry }\end{array}$ & $\begin{array}{l}\text { AMPLATZER } \\
\text { Amulet }^{\mathrm{TM}}\end{array}$ & $\begin{array}{l}\text { None, small } \\
(<3 \mathrm{~mm}), \text { medium } \\
(3-5 \mathrm{~mm}), \text { large } \\
(>5 \mathrm{~mm})\end{array}$ & $1.6 \%$ were $\geq 3 \mathrm{~mm}$ & No PDL in 18 DRTs \\
\hline Nguyen et al. [24] & 77 & $\begin{array}{l}\text { Prospective } \\
\text { observational registry }\end{array}$ & $\begin{array}{l}\text { WATCHMAN }^{\mathrm{TM}} \& \\
\text { AMPLATZER }^{\mathrm{TM}} \\
\text { cardiac plug, } \\
\text { Amulet }^{\mathrm{TM}}\end{array}$ & $\begin{array}{l}\text { Passage of contrast } \\
\text { into LAA in } \\
\text { CCTA }\end{array}$ & $\begin{array}{l}56.7 \% \text { (no } P D L \text { of }>5 \\
\text { mm observed) }\end{array}$ & $\begin{array}{l}\text { The incidence of MACE } \\
\text { was } 12.0 \text { versus } 4.3 \% \\
\text { between patients with } \\
\text { PDL and without PDL } \\
(\mathrm{p}=\mathrm{ns})\end{array}$ \\
\hline Pracon et al. [27] & 99 & $\begin{array}{l}\text { Prospective } \\
\text { observational registry }\end{array}$ & $\begin{array}{l}\text { WATCHMAN }{ }^{\mathrm{TM}} \& \\
\text { AMPLATZER }^{\mathrm{TM}} \\
\text { cardiac plug }\end{array}$ & $\geq 5 \mathrm{~mm}$ & $8 \%$ & $\begin{array}{l}\text { No association with } \\
\text { DRT ( } 0 \text { of } 7 \text { DRT })\end{array}$ \\
\hline Fink et al. [30] & 48 & Retrospective study & LARIAT $^{\circledR}$ & $\begin{array}{l}\text { Major }(>5 \mathrm{~mm}) \text {, } \\
\text { intermediate } \\
(3-5 \mathrm{~mm}), \text { minor } \\
(<3 \mathrm{~mm})\end{array}$ & $\begin{array}{l}34 \% \text { at median } 183 \\
\text { days ( } 11 \% \text { major, } 14 \% \\
\text { intermediate, } 9 \% \\
\text { minor) }\end{array}$ & $\begin{array}{l}\text { Only } 1 \\
\text { thromboembolism case } \\
\text { (without residual leak) }\end{array}$ \\
\hline Saw et al. [23] & 339 & Retrospective study & $\begin{array}{l}\text { AMPLATZER TM } \\
\text { cardiac plug }\end{array}$ & $\begin{array}{l}\text { Minimal }(<1 \mathrm{~mm}) \text {, } \\
\text { mild }(1-3 \mathrm{~mm}) \\
\text { moderate } \\
(3-5 \mathrm{~mm}), \text { severe } \\
(>5 \mathrm{~mm})\end{array}$ & $\begin{array}{l}12.5 \%(39 / 339)(2 / 39 \\
\text { were severe PDL) }\end{array}$ & No association \\
\hline Boersma et al. [26] & 1,025 & $\begin{array}{l}\text { Prospective } \\
\text { observational registry } \\
\text { (EWOLUTION) }\end{array}$ & WATCHMAN $^{\mathrm{TM}}$ & $\leq 5 \mathrm{~mm},>5 \mathrm{~mm}$ & $\begin{array}{l}8.6 \% ; 7.9 \% \leq 5 \mathrm{~mm} \\
0.7 \%>5 \mathrm{~mm}\end{array}$ & No association \\
\hline Tzikas et al. [53] & 1,047 & $\begin{array}{l}\text { Prospective } \\
\text { observational registry }\end{array}$ & $\begin{array}{l}\text { AMPLATZER }^{\mathrm{TM}} \\
\text { cardiac plug }\end{array}$ & $\begin{array}{l}\text { Trivial }(<1 \mathrm{~mm}) \text {, } \\
\text { mild }(1-3 \mathrm{~mm}) \text {, } \\
\text { or significant } \\
(>3 \mathrm{~mm})\end{array}$ & $\begin{array}{l}11.6 \% \text { total. trivial, } \\
\text { mild, and significant } \\
\text { in } 4.3,5.4 \text { and } 1.9 \%\end{array}$ & $\begin{array}{l}\text { No association for } 9 \\
\text { strokes }\end{array}$ \\
\hline $\begin{array}{l}\text { Pillarisetti et al. } \\
{[28]}\end{array}$ & 478 & $\begin{array}{l}\text { Prospective } \\
\text { observational registry }\end{array}$ & $\begin{array}{l}\text { WATCHMAN }^{\mathrm{TM}} \\
(n=219) \& \\
\text { LARIAT }^{\circledR}(n=259)\end{array}$ & $\begin{array}{l}\text { Minor }(\leq 5 \mathrm{~mm}) \text { or } \\
\text { major }(>5 \mathrm{~mm})\end{array}$ & $\begin{array}{l}21 \% \text { (Watchman), } \\
33 \% \text { (lariat) }(p= \\
0.019)\end{array}$ & $\begin{array}{l}\text { No association in both } \\
\text { devices }\end{array}$ \\
\hline Aryana et al. [35] & 72 & $\begin{array}{l}\text { Prospective } \\
\text { observational registry }\end{array}$ & $\begin{array}{l}\text { Surgical suture } \\
\text { ligation }\end{array}$ & $\begin{array}{l}\text { Passage of contrast } \\
\text { into LAA in } \\
\text { CCTA }\end{array}$ & $24 \%(17 / 72)$ & $\begin{array}{l}\text { Significantly increased } \\
\text { risk of ischemic stroke } \\
\text { and systemic } \\
\text { embolization ( } 1 / 46 \text { of } \\
\text { complete closure vs. } \\
4 / 17 \text { of incomplete } \\
\text { ligation vs. } 0 / 9 \text { of LAA } \\
\text { stump, } p=0.006)\end{array}$ \\
\hline Holmes et al. [9] & 407 & $\begin{array}{l}\text { Prospective } \\
\text { randomized trial } \\
\text { (PREVAIL) }\end{array}$ & $\begin{array}{l}\text { WATCHMAN }^{\mathrm{TM}} \\
(n=269) \text { \& oral } \\
\text { anticoagulants } \\
(n=138)\end{array}$ & $\begin{array}{l}<5 \mathrm{~mm} \text { and } \geq 5 \\
\mathrm{~mm}\end{array}$ & $10 \%<5 \mathrm{~mm}$ & No association \\
\hline Price et al. [17] & 154 & Retrospective study & LARIAT $^{\circledR}$ & $\begin{array}{l}\text { Major } \geq 5 \mathrm{~mm}) \\
\text { Minor }(<5 \mathrm{~mm})\end{array}$ & $\begin{array}{l}\text { Total } 20 \% ; 14 \%(9 / 63) \\
\text { minor, } 6 \%(4 / 63) \\
\text { major }\end{array}$ & No association \\
\hline
\end{tabular}


Table 1 (continued)

\begin{tabular}{|c|c|c|c|c|c|c|}
\hline Authors & $\begin{array}{l}\text { Study } \\
\text { population }\end{array}$ & Type of study & Type of LAA closure & Severity of leak ${ }^{*}$ & $\begin{array}{l}\text { Incidence of PDL or } \\
\text { leak, } \%^{\dagger}\end{array}$ & $\begin{array}{l}\text { Association with } \\
\text { thromboembolism }\end{array}$ \\
\hline Reddy et al. [54] & 150 & $\begin{array}{l}\text { Prospective non- } \\
\text { randomized study } \\
\text { (ASAP) }\end{array}$ & WATCHMAN $^{\top M}$ & $\begin{array}{l}\text { Minor }(<1 \mathrm{~mm}) \text {, } \\
\text { moderate }(1-3 \\
\mathrm{mm}) \text { or major }(>3 \\
\mathrm{mm})\end{array}$ & & $\begin{array}{l}\text { No association with } \\
\text { total } 4 \text { strokes } \\
6 \text { DRT with } 1 \text { stroke }\end{array}$ \\
\hline Bartus et al. [16] & 89 & $\begin{array}{l}\text { Prospective } \\
\text { observational registry }\end{array}$ & LARIAT $^{\circledR}$ & $<2 \mathrm{~mm}, 2-3 \mathrm{~mm}$ & $\begin{array}{l}4 \%(3 / 85)<2 \mathrm{~mm}, 1 \% \\
(1 / 85) 2-3 \mathrm{~mm}\end{array}$ & $\begin{array}{l}\text { No events during } \\
\text { follow-up period }\end{array}$ \\
\hline $\begin{array}{l}\text { Kanderian et al. } \\
{[34]}\end{array}$ & 137 & Retrospective study & $\begin{array}{l}\text { Surgical excision } \\
(n=52) \text {, exclusion } \\
\text { by suture }(n=73) \text {, } \\
\text { or stapler }(n=12)\end{array}$ & $\begin{array}{l}\text { Persistent LAA } \\
\text { flow }\end{array}$ & $\begin{array}{l}34 \%(47 / 137) ; 61 \% \\
(44 / 73) \text { in suture } \\
\text { exclusion, } 25 \%(3 / 12) \\
\text { in stapler exclusion }\end{array}$ & $\begin{array}{l}11 \text { versus } 15 \% \text { of stroke/ } \\
\text { TIA between successful } \\
\text { versus unsuccessful } \\
\text { closure }(p=0.61)\end{array}$ \\
\hline
\end{tabular}

LAA, left atrial appendage; AF, atrial fibrillation; CCTA, computed tomography angiography; MACE, major adverse cardiac event; PDL, peri-device leak; DRT, device-related thrombus; W, WATCHMAN; L, Lariat; TEE, transesophageal echocardiography; TIA, transient ischemic attack. * Severity of the leak were measured by color jet size from color Doppler during TEE or intracardiac echocardiography unless otherwise described. ${ }^{\dagger}$ Incidence of the leak is at 12 months after LAA closure.

from PROTECT-AF, PREVAIL, CAP, and CAP 2 by Dukkipati and colleagues [36] reported that $25 \%$ of patients with DRT had an ischemic stroke or SE incomparison with $6.8 \%$ in those without DRT (3.6-fold increased risk of adjusted stroke or SE). There is a probable causal relationship between DRT and stroke/SE, since a stroke has been reported to occur within 2 months of DRT detection in about $50 \%$ of patients who had DRT and stroke. It has not been clearly revealed whether PDL is related to DRT or not due to the limited size of the studies, but DRT is mostly on the central metal screw of the occlude devices which is far from the site of PDL $[14,27]$. It still remains uncertain for the management of DRT including imaging, follow-up, prevention, and treatment.

A thrombus that sits entirely inside a covered but leaky LAA is less likely to come off the semi-enclosed dead space since bidirection flow across the closure device is limited particularly in patients with AF. However, the clot can propagate and extend into the LA, this scenario along with thrombus formation in the outside of the closure device are both subject to embolization due to flow dynamics from LA to LV and to rest of the body.

\section{Imaging Assessment for the Leak after LAA Closure}

Patients who underwent LAA closure will need comprehensive follow-up with imaging studies, including TEE and/or CCTA to assess the leak or PDL. Nguyen et al. [24] compared TEE and CCTA in detection of the leak among patients who had ACP, Amulet, or WATCHMAN. There was a high incidence of PDL with CT evaluation (64.3\% at 3 months and $56.7 \%$ at 12 months) compared to TTE evaluation (7.1\% at 3 months). CCTA showed higher sensitivity than TEE for the detection of the leak. Saw et al. [23] also showed similar result showing the leak of $63.6 \%$ at $1-6$ months $[23,37]$. While TEE can provide real-time assessment and actual flow velocity of the leak and is a more popular imaging tool for the follow-up, the need for patients to undergo conscious sedation or general anesthesia prevents frequent follow-up. Surveillance with CCTA, however, has the advantages of high sensitivity, more comprehensive information, and easy repeatability. CCTA also provides the potential a better understanding of leak severity, longterm history of the leak, and prognosis of the leak. All these advantages over TTE can help physicians plan their treatment strategy appropriately, especially for cases with complex anatomy.

\section{Management of the Leak after LAA Closure}

Currently, there is no consensus for the optimal management strategy for the leaks or PDL. Nevertheless, there has been an increasing concern on the role of the leaks in developing thromboembolic events [38]. PDLs $>5 \mathrm{~mm}$ have been considered as a significant leak and is now managed with continued oral anticoagulation and serial TEE follow-up [22, 39]. But this might not be a plausible solution since LAA closures are often performed in patients who cannot accept the long-term oral anticoagulation due to their bleeding diathesis. Therefore, interventional managements of the residual leak have been increasing to reduce the potential risk of the leaks causing thromboembolism. Repeat repositioning of a device to decrease the presence of a PDL may not be justified due to the potential increased risk of injury to the LAA, device embolization, or procedure-related pericardial bleeding [40]. However, the placement of a second LAA occluder using AMPLATZER $^{\mathrm{TM}}$ vascular plug is an alternative treatment with adequate safety and success, particularly in patients with large leaks or residual accessory lobes who are not capable of taking long-term oral anticoagulants [41, 42]. Detachable embolization coils are also promising in closing a PDL after LAA closure [43]. Preliminary data from the TREASURE (Transcatheter Leak Closure With Detachable Coils Following Incomplete Left Atrial Appendage Closure Procedures) trial (NCT 03503253) showed that the detachable coil implantation on the residual leak site led to a $92.7 \%$ of reduc- 
tion in leak size and $93.3 \%$ of success rate [44]. A central leak from epicardial closure or surgical ligation can also be managed with nitinol-based occluders, vascular plugs, or coils [45-48].

The long-term safety and efficacy of percutaneous management of the leaks have been proved in multiple large studies mostly for paravalvular leaks [49-51]. Since incomplete LAA closure or the leaks are actively managed with the secondary interventional approaches, further studies regarding the long-term outcomes of percutaneous management of the leaks after LAA closure is warranted.

\section{Conclusion}

Residual leak is a common finding in patients who underwent LAA closure for preventing thromboembolism. The assessment of leaks should be standardized among various occluding devices/methods and imaging modalities (TEE and/or CCTA). Data regarding the rate and clinical impact of PDLs are limited or mostly underpowered. Nevertheless, the incidence of severe PDL following LAA closure is non-negligible, and there is currently no clear evidence-based management strategy available for these leaks. Therefore, larger and longer term randomized studies to better delineate the rate and clinical importance of PDLs are warranted. The CHAMPION-AF trial will prospectively compare the outcomes of LAA closure between the new-generation devices WATCHMAN FLX and NOAC. The CATALYST trial (NCT04226547) will provide further evidence of Amplatzer Amulet compared to NOAC. The ongoing aMAZE trial (NCT02513797) using Lariat suture adjunctive to pulmonary vein isolation in $\mathrm{AF}$ patients is also interesting. The ATLAS (NCT02701062) or LAAOS III (NCT01561651) trials will provide more evidence for the efficacy of surgical LAA ligation for stroke prevention. Further study examining the long-term impact of PDL treatment either by oral anticoagulation or percutaneous device closure is needed as well.

\section{Acknowledgements}

We thank all members of the Dalio Institute of Cardiovascular Imaging for stimulating discussions.

\section{Statement of Ethics}

The paper is exempt from Ethical Committee approval because this is a review paper without patient data.

\section{Conflict of Interest Statement}

The authors have no conflicts of interest.

\section{Funding Sources}

Not applicable.

\section{Author Contributions}

S.-J.J., S.C.W., and B.M. designed the review topic and provided general scope of the review. S.-J.J and B.M. performed the literature search and wrote the main manuscript. S.-J.J. and S.C.W. contributed to the detailed and current opinions on the procedures. S.-J.J. generated Figure 1 and Table 1.

\section{References}

1 Sherif HM. The developing pulmonary veins and left atrium: implications for ablation strategy for atrial fibrillation. Eur J Cardiothorac Surg. 2013 Nov;44(5):792-9.

2 Blackshear JL, Odell JA. Appendage obliteration to reduce stroke in cardiac surgical patients with atrial fibrillation. Ann Thorac Surg. 1996 Feb;61(2):755-9.

3 Camm AJ, Lip GY, De Caterina R, Savelieva I, Atar D, Hohnloser SH, et al. 2012 focused update of the ESC Guidelines for the management of atrial fibrillation: an update of the 2010 ESC Guidelines for the management of atrial fibrillation. Developed with the special contribution of the European Heart Rhythm Association. Eur Heart J. 2012 Nov;33(21):2719-47.

4 January CT, Wann LS, Calkins H, Chen LY, Cigarroa JE, Cleveland JC Jr, et al. 2019 AHA/ ACC/HRS focused update of the 2014 AHA/
ACC/HRS Guideline for the management of patients with atrial fibrillation: a report of the American College of cardiology/American Heart Association task force on clinical practice guidelines and the heart rhythm society. J Am Coll Cardiol. 2019 Jul 9;74(1):104-32.

5 Deitelzweig S, Farmer C, Luo X, Li X, Vo L, Mardekian J, et al. Comparison of major bleeding risk in patients with non-valvular atrial fibrillation receiving direct oral anticoagulants in the real-world setting: a network meta-analysis. Curr Med Res Opin. 2018 Mar;34(3):487-98.

6 Osmancik P, Herman D, Neuzil P, Hala P, Taborsky M, Kala $\mathrm{P}$, et al. Left atrial appendage closure versus direct oral anticoagulants in high-risk patients with atrial fibrillation. J Am Coll Cardiol. 2020 Jun 30;75(25):3122-35.

7 Holmes DR, Reddy VY, Turi ZG, Doshi SK, Sievert H, Buchbinder M, et al. Percutaneous clo- sure of the left atrial appendage versus warfarin therapy for prevention of stroke in patients with atrial fibrillation: a randomised non-inferiority trial. Lancet. 2009 Aug 15;374(9689):534-42.

8 Reddy VY, Doshi SK, Sievert H, Buchbinder M, Neuzil P, Huber K, et al. Percutaneous left atrial appendage closure for stroke prophylaxis in patients with atrial fibrillation: 2.3year follow-up of the PROTECT AF (Watchman left atrial appendage system for embolic protection in patients with atrial fibrillation) trial. Circulation. 2013 Feb 12;127(6):720-9.

9 Holmes DR Jr, Kar S, Price MJ, Whisenant B, Sievert H, Doshi SK, et al. Prospective randomized evaluation of the Watchman left atrial appendage closure device in patients with atrial fibrillation versus long-term warfarin therapy: the PREVAIL trial. J Am Coll Cardiol. 2014 Jul 8;64(1):1-12. 
10 Reddy VY, Sievert H, Halperin J, Doshi SK, Buchbinder M, Neuzil P, et al. Percutaneous left atrial appendage closure vs. warfarin for atrial fibrillation: a randomized clinical trial. JAMA. 2014 Nov 19;312(19):1988-98.

11 Reddy VY, Holmes D, Doshi SK, Neuzil P, Kar S. Safety of percutaneous left atrial appendage closure: results from the Watchman left atrial appendage system for embolic protection in patients with AF (PROTECT AF) clinical trial and the continued access registry. Circulation. 2011 Feb 1;123(4):417-24.

12 Holmes DR Jr, Reddy VY, Gordon NT, Delurgio D, Doshi SK, Desai AJ, et al. Long-term safety and efficacy in continued access left atrial appendage closure registries. J Am Coll Cardiol. 2019 Dec 10;74(23):2878-89.

13 Reddy VY, Gibson DN, Kar S, O’Neill W, Doshi SK, Horton RP, et al. Post-approval U.S. Experience with left atrial appendage closure for stroke prevention in atrial fibrillation. J Am Coll Cardiol. 2017 Jan 24;69(3):253-61.

14 Landmesser U, Tondo C, Camm J, Diener HC, Paul V, Schmidt B, et al. Left atrial appendage occlusion with the AMPLATZER Amulet device: one-year follow-up from the prospective global Amulet observational registry. EuroIntervention. 2018 Aug 3;14(5): e590-e97.

15 Hildick-Smith D, Landmesser U, Camm AJ, Diener HC, Paul V, Schmidt B, et al. Left atrial appendage occlusion with the Amplatzer Amulet device: full results of the prospective global observational study. Eur Heart J. 2020 Aug 7;41(30):2894-901.

16 Bartus K, Han FT, Bednarek J, Myc J, Kapelak B, Sadowski J, et al. Percutaneous left atrial appendage suture ligation using the LARIAT device in patients with atrial fibrillation: initial clinical experience. J Am Coll Cardiol. 2013 Jul 9;62(2):108-18.

17 Price MJ, Gibson DN, Yakubov SJ, Schultz JC, Di Biase L, Natale A, et al. Early safety and efficacy of percutaneous left atrial appendage suture ligation: results from the U.S. transcatheter LAA ligation consortium. J Am Coll Cardiol. 2014 Aug 12;64(6):565-72.

18 Crystal E, Lamy A, Connolly SJ, Kleine P, Hohnloser SH, Semelhago L, et al. Left Atrial Appendage Occlusion Study (LAAOS): a randomized clinical trial of left atrial appendage occlusion during routine coronary artery bypass graft surgery for long-term stroke prevention. Am Heart J. 2003 Jan;145(1):174-8.

19 Whitlock RP, Vincent J, Blackall MH, Hirsh J, Fremes S, Novick R, et al. Left Atrial Appendage Occlusion Study II (LAAOS II). Can J Cardiol. 2013 Nov;29(11):1443-7.

20 Lee R, Vassallo P, Kruse J, Malaisrie SC, Rigolin $\mathrm{V}$, Andrei AC, et al. A randomized, prospective pilot comparison of 3 atrial appendage elimination techniques: internal ligation, stapled excision, and surgical excision. J Thorac Cardiovasc Surg. 2016 Oct;152(4):1075-80.

21 Su P, McCarthy KP, Ho SY. Occluding the left atrial appendage: anatomical considerations. Heart. 2008 Sep;94(9):1166-70.
22 Raphael CE, Friedman PA, Saw J, Pislaru SV, Munger TM, Holmes DR Jr. Residual leaks following percutaneous left atrial appendage occlusion: assessment and management implications. EuroIntervention. 2017 Nov 20; 13(10):1218-25.

23 Saw J, Tzikas A, Shakir S, Gafoor S, Omran H, Nielsen-Kudsk JE, et al. Incidence and clinical impact of device-associated thrombus and peri-device leak following left atrial appendage closure with the amplatzer cardiac plug. JACC Cardiovasc Interv. 2017 Feb 27;10(4): 391-9.

24 Nguyen A, Gallet R, Riant E, Deux JF, Boukantar M, Mouillet G, et al. Peridevice leak after left atrial appendage closure: incidence, risk factors, and clinical impact. Can J Cardiol. 2019 Apr;35(4):405-12.

25 Viles-Gonzalez JF, Kar S, Douglas P, Dukkipati S, Feldman T, Horton R, et al. The clinical impact of incomplete left atrial appendage closure with the Watchman device in patients with atrial fibrillation: a PROTECT AF (percutaneous closure of the left atrial appendage versus warfarin therapy for prevention of stroke in patients with atrial fibrillation) substudy. J Am Coll Cardiol. 2012 Mar 6;59(10): 923-9.

26 Boersma LV, Schmidt B, Betts TR, Sievert H, Tamburino C, Teiger E, et al. Implant success and safety of left atrial appendage closure with the WATCHMAN device: peri-procedural outcomes from the EWOLUTION registry. Eur Heart J. 2016 Aug;37(31):2465-74.

27 Pracon R, Bangalore S, Dzielinska Z, Konka M, Kepka C, Kruk M, et al. Device thrombosis after percutaneous left atrial appendage occlusion is related to patient and procedural characteristics but not to duration of postimplantation dual antiplatelet therapy. Circ Cardiovasc Interv. 2018 Mar;11(3):e005997.

28 Pillarisetti J, Reddy YM, Gunda S, Swarup V, Lee R, Rasekh A, et al. Endocardial (Watchman) vs. epicardial (Lariat) left atrial appendage exclusion devices: understanding the differences in the location and type of leaks and their clinical implications. Heart Rhythm. 2015 Jul;12(7):1501-7.

29 Kleinecke C, Gloekler S, Meier B. Utilization of percutaneous left atrial appendage closure in patients with atrial fibrillation: an update on patient outcomes. Expert Rev Cardiovasc Ther. 2020 Aug;18(8):517-30.

30 Fink T, Schlüter M, Tilz RR, Heeger CH, Lemes C, Maurer T, et al. Acute and long-term outcomes of epicardial left atrial appendage ligation with the second-generation LARIAT device: a high-volume electrophysiology center experience. Clin Res Cardiol. 2018 Dec; 107(12):1139-47.

31 Kamp O, Verhorst PM, Welling RC, Visser CA. Importance of left atrial appendage flow as a predictor of thromboembolic events in patients with atrial fibrillation. Eur Heart J. 1999 Jul;20(13):979-85.

32 Caliskan E, Sahin A, Yilmaz M, Seifert B, Hinzpeter R, Alkadhi H, et al. Epicardial left atrial appendage AtriClip occlusion reduces the incidence of stroke in patients with atrial fibrillation undergoing cardiac surgery. Europace. 2018 Jul 1;20(7):e105-e14.

33 Katz ES, Tsiamtsiouris T, Applebaum RM, Schwartzbard A, Tunick PA, Kronzon I. Surgical left atrial appendage ligation is frequently incomplete: a transesophageal echocardiograhic study. J Am Coll Cardiol. 2000 Aug; 36(2):468-71.

34 Kanderian AS, Gillinov AM, Pettersson GB, Blackstone E, Klein AL. Success of surgical left atrial appendage closure: assessment by transesophageal echocardiography. J Am Coll Cardiol. 2008 Sep 9;52(11):924-9.

35 Aryana A, Singh SK, Singh SM, O’Neill PG, Bowers MR, Allen SL, et al. Association between incomplete surgical ligation of left atrial appendage and stroke and systemic embolization. Heart Rhythm. 2015 Jul;12(7):14317.

36 Dukkipati SR, Kar S, Holmes DR, Doshi SK, Swarup V, Gibson DN, et al. Device-related thrombus after left atrial appendage closure: incidence, predictors, and outcomes. Circulation. 2018 Aug 28;138(9):874-85.

37 Saw J, Fahmy P, DeJong P, Lempereur M, Spencer R, Tsang M, et al. Cardiac CT angiography for device surveillance after endovascular left atrial appendage closure. Eur Heart J Cardiovasc Imaging. 2015 Nov; 16(11): 1198-206.

38 Fender EA, El Sabbagh A, Al-Hijji M, Holmes DR Jr. Left atrial appendage peridevice leak presenting with stroke. JACC Cardiovasc Interv. 2019 Jul 22;12(14):e123-e25.

39 Asmarats L, Rodés-Cabau J. Percutaneous left atrial appendage closure: current devices and clinical outcomes. Circ Cardiovasc Interv. 2017 Nov; 10(11):e005359.

40 Wolfrum M, Attinger-Toller A, Shakir S, Gloekler S, Seifert B, Moschovitis A, et al. Percutaneous left atrial appendage occlusion: effect of device positioning on outcome. Catheter Cardiovasc Interv. 2016 Oct;88(4):65664.

41 Alkhouli M, Alqahtani F, Kazienko B, Olgers K, Sengupta PP. Percutaneous closure of peridevice leak after left atrial appendage occlusion. JACC Cardiovasc Interv. 2018 Jun 11; 11(11):e83-5.

42 Alkhouli M, Chaker Z, Al-Hajji M, Sengupta PP. Management of peridevice leak following left atrial appendage occlusion. JACC Clin Electrophysiol. 2018 Jul;4(7):967-9.

43 Della Rocca DG, Horton RP, Di Biase L, Bassiouny M, Al-Ahmad A, Mohanty S, et al. First experience of transcatheter leak occlusion with detachable coils following left atrial appendage closure. JACC Cardiovasc Interv. 2020 Feb 10;13(3):306-19.

44 Transcatheter leak closure with detachable coils following incomplete left atrial appendage closure procedures (TREASURE) (ClinicalTrials.gov website). 2019 Mar 14. Available from: https: //clinicaltrials.gov/ct2/show/ NCT03503253 Accessed 2020 Oct 29. 
45 Mosley WJ 2nd, Smith MR, Price MJ. Percutaneous management of late leak after lariat transcatheter ligation of the left atrial appendage in patients with atrial fibrillation at high risk for stroke. Catheter Cardiovasc Interv. 2014 Mar 1;83(4):664-9.

46 Pillai AM, Kanmanthareddy A, Earnest M, Reddy M, Ferrell R, Nath J, et al. Initial experience with post Lariat left atrial appendage leak closure with Amplatzer septal occluder device and repeat Lariat application. Heart Rhythm. 2014 Nov;11(11):1877-83.

47 Yeow WL, Matsumoto T, Kar S. Successful closure of residual leak following LARIAT procedure in a patient with high risk of stroke and hemorrhage. Catheter Cardiovasc Interv. 2014 Mar 1;83(4):661-3.
48 Wunderlich NC, Franke J, Kuex H. Transcatheter closure of a residual leak after surgical left atrial appendage ligation. Eur Heart J Cardiovasc Imaging. 2019 Jul 1;20(7):841.

49 Sorajja P, Cabalka AK, Hagler DJ, Rihal CS. Long-term follow-up of percutaneous repair of paravalvular prosthetic regurgitation. J Am Coll Cardiol. 2011 Nov 15;58(21):2218-24.

50 Saia F, Martinez C, Gafoor S, Singh V, Ciuca C, Hofmann I, et al. Long-term outcomes of percutaneous paravalvular regurgitation closure after transcatheter aortic valve replacement: a multicenter experience. JACC Cardiovasc Interv. 2015 Apr 27;8(5):681-8.

51 Alkhouli M, Rihal CS, Zack CJ, Eleid MF, Maor E, Sarraf M, et al. Transcatheter and surgical management of mitral paravalvular leak: long-term outcomes. JACC Cardiovasc Interv. 2017 Oct 9;10(19):1946-56.
52 Doshi SK. Primary outcome evaluation of a next generation LAAC device: the PINNACLE FLX trial. Presented at: Heart Rhtym Society 2020. 2020 May 8.

53 Tzikas A, Shakir S, Gafoor S, Omran H, Berti S, Santoro G, et al. Left atrial appendage occlusion for stroke prevention in atrial fibrillation: multicentre experience with the AMPLATZER cardiac plug. EuroIntervention. 2016 Feb;11(10):1170-9.

54 Reddy VY, Möbius-Winkler S, Miller MA, Neuzil P, Schuler G, Wiebe J, et al. Left atrial appendage closure with the Watchman device in patients with a contraindication for oral anticoagulation: the ASAP study (ASA Plavix Feasibility Study With Watchman Left Atrial Appendage Closure Technology). J Am Coll Cardiol. 2013 Jun 25;61(25):2551-6. 